\title{
VPR Gene
}

National Cancer Institute

\section{Source}

National Cancer Institute. VPR Gene. NCI Thesaurus. Code C19124.

This HIV gene, which encodes protein vpr, is involved in both virus replication and viral genome integration. 